\title{
Polymerase Chain Reaction-Based Detection of Spiroplasma citri Associated with Citrus Stubborn Disease
}

\author{
Raymond K. Yokomi, United States Department of Agriculture-Agricultural Research Service (USDA-ARS), Par- \\ lier, CA 93648; Alexandre F. S. Mello, Department of Entomology and Plant Pathology, Oklahoma State University, \\ Stillwater 74078; Maria Saponari, USDA-ARS, Parlier; and Jacqueline Fletcher, Department of Entomology and \\ Plant Pathology, Oklahoma State University
}

\begin{abstract}
Yokomi, R. K., Mello, A. F. S., Saponari, M., and Fletcher, J. 2008. Polymerase chain reactionbased detection of Spiroplasma citri associated with citrus stubborn disease. Plant Dis. 92:253260 .

Polymerase chain reaction (PCR)-based detection of citrus stubborn disease was improved using primers based on sequences of the P89 putative adhesin gene and the P58 putative adhesin multigene of Spiroplasma citri. Real-time PCR also was developed with detection limits estimated to be between $10^{-4}$ and $10^{-4}$ ng by serial dilution of a recombinant $S$. citri plasmid into DNA extracts from healthy Madam Vinous sweet orange. PCR for the detection of $S$. citri by these new primers was validated by comparing culturing of the pathogen, the traditional method of diagnosis, with PCR assays from samples taken from two citrus plots in Kern County, CA. Fruit columella was collected from 384 and 377 individual trees in each of two fields, respectively; one portion was used for culturing and the other for DNA extraction and PCR. PCR results matched those of culturing 85 to $100 \%$ of the time depending on the primers used. More importantly, PCR detected $S$. citri from culture-negative trees in 5 to $15 \%$ of the cases, suggesting that PCR performed as well or better than culturing for detection of $S$. citri in field samples. Realtime PCR proved to be the best method for detection. Differential reaction of the samples to the P58 primer pairs suggested that two populations of $S$. citri occur in historical and present-day field isolates. Citrus stubborn disease incidence was estimated to be 58.3 and $3.7 \%$ in the two orchards. The results presented here support the use of PCR for reliable detection of S. citri in field trees.
\end{abstract}

Additional keyword: epidemiology

Citrus stubborn disease is caused by Spiroplasma citri, a leafhopper-transmitted, phloem-limited spiroplasma. The pathogen infects most citrus species and cultivars as well as a wide range of noncitrus plants. Citrus stubborn is an important disease of young citrus in several hot and arid citrusgrowing regions, including California, Arizona, most of North Africa, the eastern Mediterranean Basin, and the Middle East (4). Although the disease is rarely lethal, affected trees can be severely stunted, with dense, abnormally upright leaves. Leaves show variable chlorotic patterns that may resemble nutritional deficiency. Off-season flowering is common, which results in

Corresponding author: R. K. Yokomi

E-mail: ray.yokomi@ars.usda.gov

Mention of trade names or commercial products in this article is solely for purposes of providing specific information and does not imply a recommendation or an endorsement.

Accepted for publication 17 September 2007.

doi:10.1094/PDIS-92-2-0253

This article is in the public domain and not copyrightable. It may be freely reprinted with customary crediting of the source. The American Phytopathological Society, 2008. various ages and sizes of fruit on the tree. Fruit often does not color at the stem end (acropetal) and seed are often aborted $(4,6,7)$. Fruit may range from normal to severely deformed when compared with healthy fruit. Yield losses due to citrus stubborn are variable but have been reported to range from 44 to $74 \%$ in Valencia orange and up to $100 \%$ in navel oranges in Riverside, CA (7).

Field diagnosis of citrus stubborn disease is difficult and often inaccurate. Foliar symptoms can resemble nutritional deficiencies. Mottling in leaves can be confused with mechanical girdling or other phloem-restricted pathogens such as huanglongbing $(4,12)$. Routine detection of $S$. citri is by culturing in cell-free liquid medium and examination of the organism for helical morphology and motility by darkfield microscopy (19). Polymerase chain reaction (PCR) detection of $S$. citri was used with primers based on gene sequences for spiralin, the most abundant membrane protein $(3,11)$. However, in our hands, these primers lacked the sensitivity needed for consistent pathogen detection from field citrus trees. Because the spiralin gene is present as a single copy in the chromosomes of all $S$. citri strains examined (11), we searched the $S$. citri genome for multiple-copy membrane protein genes from which to develop primers that yield greater sensitivity in a PCR assay. Here, we report that, for citrus stubborn disease diagnosis, PCR was significantly more sensitive when primer sequences were designed from either genes P89 or P58 than from the spiralin gene. P89 is a putative adhesin protein gene present on a plasmid as well as in the $S$. citri genome. P58 is a putative adhesin multigene. Further, the utility of PCR using the new primers for pathogen detection from samples taken from field trees is shown. Evidence also is presented for the presence of two strains of $S$. citri in orchards in Kern County, CA and in strains maintained in planta since the 1960s in California.

\section{MATERIALS AND METHODS}

Pathogen isolation and cultivation. Citrus leaves and fruit were collected from field Navel orange (Citrus sinensis (L.)) trees as well as $S$. citri-infected Madam Vinous sweet orange $(C$. sinensis (L.)) seedlings maintained in a greenhouse. Petiole leaf midribs or fruit columella were excised, surface sterilized, and diced with a sterile razor blade in $5 \mathrm{ml}$ of LD8 broth medium (14), passed through a $0.45-\mu \mathrm{m}$ filter, and incubated at $30^{\circ} \mathrm{C}$. Presence of $S$. citri was confirmed after 3 to 14 days by examining $10 \mu \mathrm{l}$ of culture medium by dark-field microscopy at $\times 400$ to 1,000 for the presence of motile, helical spiroplasmas.

In planta cultures of three strains of $S$. citri (S600, S616, and C189), kindly provided by the Citrus Clonal Protection Program (CCPP), University of California, Riverside (UCR) and the Central California Tristeza Eradication Agency, Tulare, served as standard isolates for this study. S600 was isolated from a symptomatic sweet orange tree from Thermal (Coachella Valley), CA collected in November 1964. S616 is a replacement source plant propagated to replace an older diseased plant from the same time period (C. N. Roistacher, personal communication). C189 is from the culture collection of E. C. Calavan, UCR, and was isolated from a Madam Vinous seedling (18). These isolates have been maintained in planta continuously at UCR since the 1960s. DNA isolated from cultures of the following spiroplasma species were obtained from 
Oklahoma State University: S. floricola, $S$. kunkelii, S. melliferum, and S. phoeniceum. Two strains of Xylella fastidiosa were kindly provided by Marta Francis, De- partment of Plant Pathology, University of California, Davis as additional negative controls. These strains were $X$. fastidiosa Ann-1 (ATCC 700598), associated with
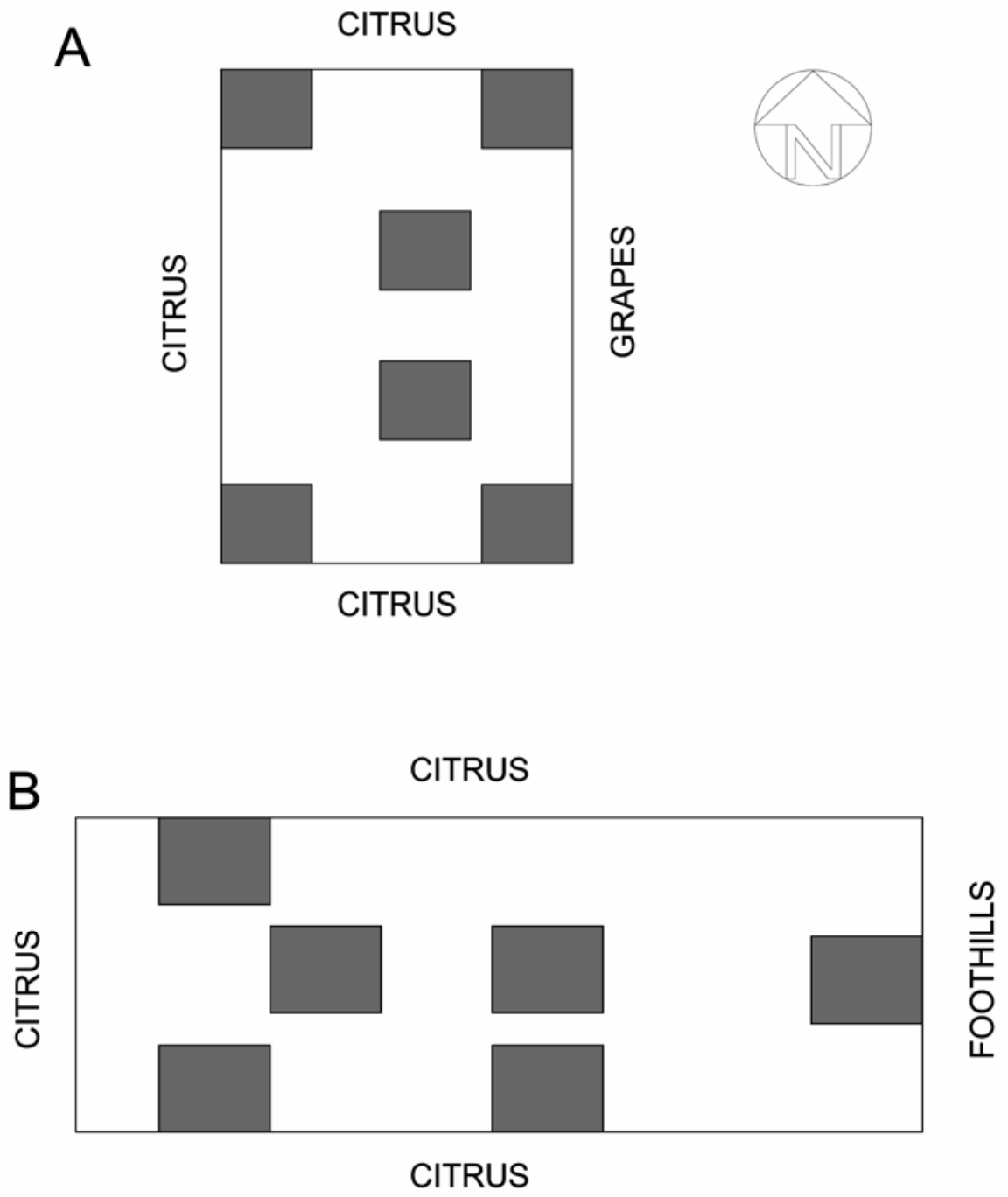

Fig. 1. Location of sampling blocks used to estimate citrus stubborn disease incidence in two 8-ha groves of sweet orange on Carrizo rootstock. Both orchards were approximately 20 years old and located in northeast Kern County, CA. In all, 384 and 377 individual tree samples were taken per field, respectively. The samples were partitioned in six blocks (depicted in gray) of 64 contiguous trees ( 8 trees by 8 rows) spaced throughout the grove. A, Barnfield Navel orange on Carrizo rootstock; B, TI Navel orange on Carrizo rootstock.

oleander leaf scorch, and Dixon (ATCC 700965), associated with almond leaf scorch.

Two strains of S. citri (designated T4 and T9) were isolated and cultured from different trees in field 1 (Fig. 1) in Kern County, CA, and were examined in greater detail in this study.

Primer design. Data queries for membrane surface proteins from the $S$. citri genome were performed for the putative adhesin gene P89 and the putative adhesinlike multigene P58. BLAST search (version 202014; http://www.ncbi.nlm.nih.gov/ BLAST/) using the nucleotide sequences as queries indicated that both genes contain sites useful for specific detection of $S$. citri. As a result, PCR primers were designed, using Lasergene 7.0 (DNASTAR) software, within the P89 gene sequences (2) derived from GenBank accessions nos. AJ969073.1, AJ969072.1, AJ969071.1, AJ969070.1, and AJ969069.1; and within two P58-like regions, GenBank accessions nos. DQ344811 and DQ344812 (8). An additional primer pair was designed within the $S$. citri spiralin gene sequence derived from GenBank accession no. U13998 (11). The primers developed and tested included spiralin-f/r; P89-f/r; P58-1f/5r; and P586f/4r (Table 1). PCR with serial dilutions of positive $S$. citri cultures and DNA extracts from field trees were used to determine limits of the detection protocols.

Separate primers for real-time PCR were developed from sequences within two P58-like regions of the $S$. citri genome using Primer Express software (Applied Biosystems). These primer pairs were P581f/2r and P58-3f/4r. (Table 1).

DNA extraction. Two hundred $\mathrm{mg}$ of fresh tissue or $100 \mathrm{mg}$ of desiccated or lyophilized tissue was homogenized in MiniBeadBeater-96 (Bio-Spec Product, Bartlesville, OK). DNA was extracted by a modified cetyltrimethylammonium bromide method (9). DNA concentrations of the extracts were determined using a NanoDrop ND-1000 UV-Vis Spectrophotometer (NanoDrop Technologies, Wil-

Table 1. Primers used for polymerase chain reaction (PCR) for the detection of Spiroplasma citri

\begin{tabular}{|c|c|c|c|c|}
\hline Primer & Target gene & $\begin{array}{l}\text { Primer sequence } \\
\qquad\left(5^{\prime} \text { to } 3^{\prime}\right)\end{array}$ & Position & $\begin{array}{c}\text { Expected } \\
\text { amplicon size (bp) }\end{array}$ \\
\hline \multicolumn{5}{|l|}{ Conventional PCR } \\
\hline Spiralin-f & Spiralin & GTCGGAACAACATCAGTGGT & $55-74^{\mathrm{a}}$ & \\
\hline Spiralin-r & Spiralin & TGCTTTTGGTGGTGCTAATG & $710-729^{\mathrm{a}}$ & 675 \\
\hline P89-f & Putative P89 adhesin gene & ATTGACTCAACAAACGGGATAA & $5,786-5,807^{\mathrm{b}}$ & \\
\hline P89-r & Putative P89 adhesin gene & CGGCGTTTGTTAATTTTTGGTA & $6,471-6,492^{b}$ & 707 \\
\hline P58-1f & Putative P58 adhesin-like gene & CACCGCATAAACCATATACTTTGAAT & $466-491^{\mathrm{c}}$ & \\
\hline $\mathrm{P} 58-5 \mathrm{r}$ & Putative P58 adhesin-like gene & GTAGCAGAATGTAACCCACGAC & $1,145-1,166^{\mathrm{c}}$ & 701 \\
\hline P58-6f & Putative P58 adhesin-like gene & GCGGACAAATTAAGTAATAAAAGAGC & $445-470^{\mathrm{d}}$ & \\
\hline P58-4r & Putative P58 adhesin-like gene & GCACAGCATTTGCCAACTACA & $874-894^{\mathrm{d}}$ & 450 \\
\hline \multicolumn{5}{|l|}{ Real-time PCR } \\
\hline P58-2r used with P58-1f & Putative P58 adhesin-like gene & TTCGCTCGCATAAGTATCATATCTTC & $526-551^{\mathrm{c}}$ & 86 \\
\hline P58-3f used with P58-4r & Putative P58 adhesin-like gene & GTCCCTAATGCACCGTGAAAA & $776-796^{\mathrm{d}}$ & 119 \\
\hline
\end{tabular}

\footnotetext{
${ }^{a}$ Nucleotide position referred to the GenBank accession number U13998 (11).

${ }^{\mathrm{b}}$ Nucleotide position referred to the GenBank accession number AJ969072.1 (2).

${ }^{\mathrm{c}}$ Nucleotide position referred to the GenBank accession number DQ344811 (8).
}

${ }^{d}$ Nucleotide position referred to the GenBank accession number DQ344812 (8). 
mington, DE, USA) and adjusted to approximately $10 \mathrm{ng}$ for further analysis.

Conventional PCR. PCR reactions were conducted with $1.0 \mu \mathrm{l}$ of DNA template in $20 \mu \mathrm{l}$ of reaction mix, which included $1 \times$ GoTaq Buffer, $0.4 \mu$ l each of 10 $\mathrm{mM}$ dNTPs (Sigma), $10 \mu \mathrm{M}$ forward primer (Invitrogen), $10 \mu \mathrm{M}$ reverse primer (Invitrogen), and $0.1 \mu \mathrm{l}$ of GoTaq (Promega). Reactions were performed on a PTC-100 Thermocyler (MJ Research) as follows: $3 \mathrm{~min}$ of denaturation at $95^{\circ} \mathrm{C}$; followed by 40 cycles of $95^{\circ} \mathrm{C}$ for $30 \mathrm{~s}$, $56^{\circ} \mathrm{C}$ for $30 \mathrm{~s}$, and $72^{\circ} \mathrm{C}$ for $90 \mathrm{~s}$; followed by $3 \mathrm{~min}$ of elongation at $72^{\circ} \mathrm{C}$.

Real-time PCR. A real-time PCR assay was developed using the DNA binding fluorophore SYBR Green I. Reactions consisted of $0.8 \mu \mathrm{M}$ each reverse and forward primers, $2 \mu \mathrm{l}$ of plant DNA extract, or $1 \mu \mathrm{l}$ or $S$. citri cell culture in a total volume of $25 \mu \mathrm{l}$ of $1 \times$ iQ SYBR Green Supermix (BioRad). Reactions were performed on a iQ5 Real-Time PCR System (BioRad). The amplification profile consisted of $95^{\circ} \mathrm{C}$ for $5 \mathrm{~min}$ followed by 45 cycles at $95^{\circ} \mathrm{C}$ for $15 \mathrm{~s}$ and $61.5^{\circ} \mathrm{C}$ for $45 \mathrm{~s}$. Control samples in each run included DNA extracts from infected and healthy plants, S. citri culture, and nontemplate control.

To check the size and the specificity of the real-time PCR products, preliminary experiments included melting curves and electrophoretic analyses. Following threshold-dependent cycling, melting was performed from 60 to $95^{\circ} \mathrm{C}$ at melt rates of $0.5^{\circ} \mathrm{C} / 10 \mathrm{~s}$. Melting peaks were visualized by plotting the absolute value of the first derivative against the temperature. For electrophoretic analysis, real-time PCR products were separated on 5\% polyacrylamide gel and bands visualized by staining with ethidium bromide.

Partial P58-like sequences were cloned in PGEMT-Easy plasmid vector (Promega). Eight fourfold serial dilutions were prepared by mixing the recombinant DNA plasmid into healthy citrus (cv. Madam Vinous) total DNA extract. The dilutions generated a standard curve to estimate the $S$. citri DNA concentration in the unknown samples. Three replicates of each dilution were tested simultaneously in the same run and three independent assays performed. Variability is reported as the coefficient of variation within or between the assays.

Plots and samples. Samples from numerous trees in our survey resulted in positive cultures of $S$. citri and allowed us to select appropriate sites for field studies. Two 20-acre Navel orange groves were selected for our study. The groves are located in northeastern Kern County and are approximately $15 \mathrm{~km}$ apart. Grove 1 was planted in 1988 as Valencia on Carrizo citrange rootstock (Fig. 1A). This field was topworked to Barnfield Navels in 1996. The grove has 1,798 trees planted in 58 rows with 31 trees per row and is surrounded by citrus and grape. Grove 2, planted in 1989, was TI Navel orange on Carrizo rootstock (Fig. 1B). This grove has 1,830 trees planted in 61 rows with 30 trees per row and is surrounded by citrus and foothills directly to the east. In 2000, young Newhall Navel orange trees were planted between the existing TI Navels within each row. For this study, both groves were partitioned into blocks of 64 contiguous trees in a configuration of 8 rows by 8 trees. To estimate citrus stubborn disease incidence, 384 individual trees from six different blocks located around each field (Fig. 1) were sampled and analyzed. The sample blocks took into account a possible edge effect as suggested by a previous report of beet leafhopper flight activity around citrus (16). This leafhopper is the key vector species of S. citri in central California (15). Samples were collected from July to November 2006.

To validate the new PCR protocols with field samples, a direct comparison of culturing and PCR for citrus stubborn disease diagnosis was performed. Because the tissue that yielded positive cultures most frequently was fruit columella, columella was sampled from three fruit per tree. Specifically, the fleshly central axis tissue immediately below the peduncle and sepal and the acropetal portion of the columella were used for culturing of the citrus stubborn agent. The remaining basipetal portion of the columella was used for DNA extraction and detection of $S$. citri using the different primer pairs in conventional and real time PCR

\section{RESULTS}

PCR with spiralin primers. PCR using spiralin- $\mathrm{f} / \mathrm{r}$ primers produced an amplicon
675 bp in size when high-titer samples, such as strain S616 cells from cultures or DNA extracts from infected plants maintained in a warm greenhouse, were used as templates (Fig. 2). The same primers, when used on samples having lower pathogen titer (such as DNA extracts from field trees), however, failed to produce amplicons even though the same samples were positive for $S$. citri based on culturing. An example of this type of discrepancy is shown in Figure 2. PCR with spiralin- $\mathrm{f} / \mathrm{r}$ primers of tissue extracts from trees T4 and T9 produced no visible amplicons, but spiroplasmas were cultured from the same trees and PCR tests on $1-\mu \mathrm{l}$ aliquots of those cultures were positive.

PCR with P89-f/r and P58-6f/4r primers. In these PCR tests, amplicons of the expected sizes of 707 and $450 \mathrm{bp}$ were readily produced using $\mathrm{P} 89-\mathrm{f} / \mathrm{r}$ and $\mathrm{P} 58$ 6f/4r primer pairs, respectively, using S616 DNA as templates (Fig. 3A and B). By serial dilutions, amplicons were detected to a level of $0.2 \mathrm{pg}$ DNA with these primers (Fig. 3A and B). Spiralin primers, in contrast, produced visible amplicons (675 bp) only to approximately $0.2 \mathrm{ng}$ (Fig. 3C).

The high sensitivity of PCR with P89$\mathrm{f} / \mathrm{r}$ and P58-6f/4r. for $S$. citri detection also resulted in some weak, nonspecific annealing and amplification of DNA fragments from $S$. floricola, S. kunkelii, $S$. melliferum, S. phoeniceum, and X. fastidiosa (Fig. 4A and B). These weak bands were not observed when spiralin gene primers were used (Fig. 4C). In contrast, however, the amplicons produced by $S$. citri templates with P89-f/r and P58-6f/4r were always very strong and clearly positive.

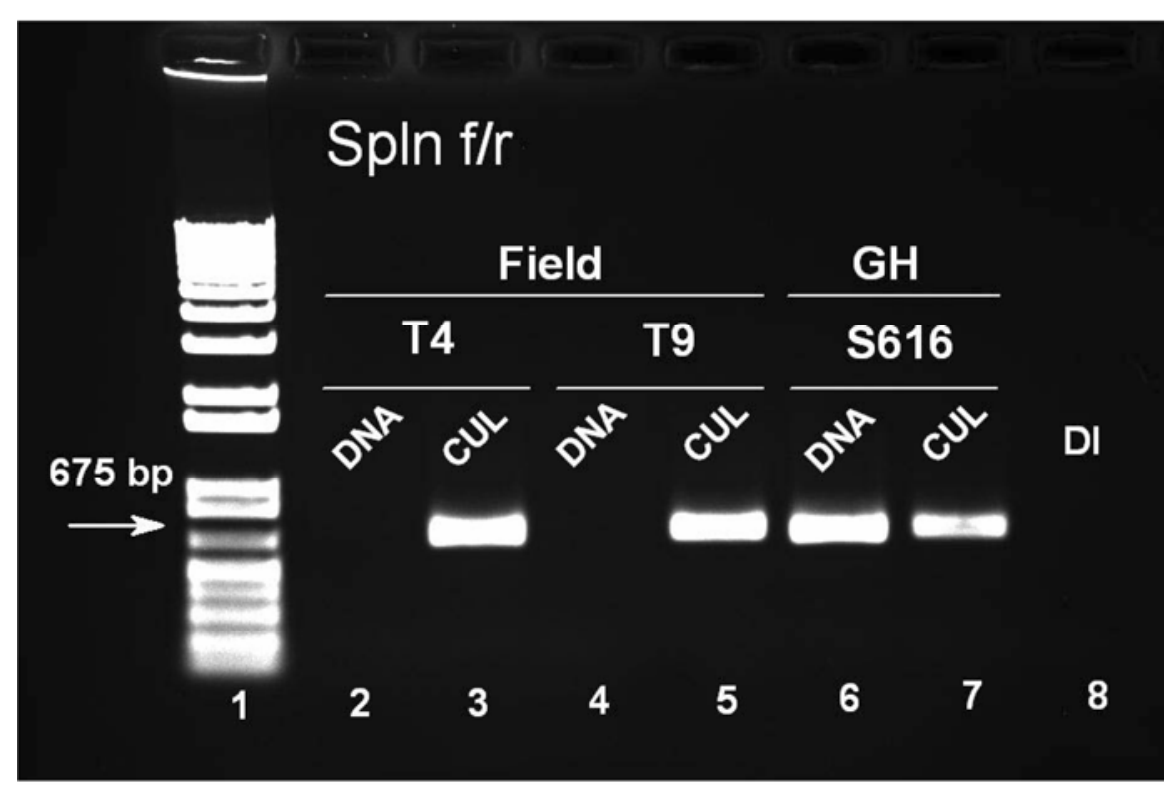

Fig. 2. Polymerase chain reaction amplicons produced using spiralin-f/r primers with Spiroplasma citri DNA extracted from plant tissue from the field and greenhouse source plants compared with that from cells directly from cultures (CUL). T4 and T9 are strains collected from the field trees in November 2006 in Kern County, CA, and S616 is from the source plant maintained in the greenhouse (GH). S616 is a strain of S. citri collected in the 1960s from the Coachella Valley, CA. Lane 1, DNA 1-kb-plus ladder; lane 7, deionized water control (DI). 
PCR with P58-6f/4r versus P58-1f/5r primer pairs. A large number of $S$. citri isolates were cultured from infected trees in the test plots. PCR of these samples with P58-1f/5r primers yielded an amplicon of $701 \mathrm{bp}$ (Fig. 5B). In PCR assays with our field isolates as well as the UCR strains S600, S616, and C189, differential reaction was noted using the two P58 primer pairs. In group 1, the isolates produced readily observable amplicons with both P58-6f/4r (450 bp) and P58-1f/5r primers (701 bp) (Fig. 5A and B). These same isolates produced amplicons when the P89-f/r primers were used (data not shown). Group 1 isolates were represented by T9, C189, and S616 (Fig. 5A and B). Group 2 isolates, exemplified by $\mathrm{T} 4$ and S600, produced the 450-bp amplicon with P58-6f/4r primers; however, no amplification occurred with P58-1f/5r primers (Fig. 5B).

Real-time PCR. Quantitative detection of $S$. citri was achieved utilizing both P58-

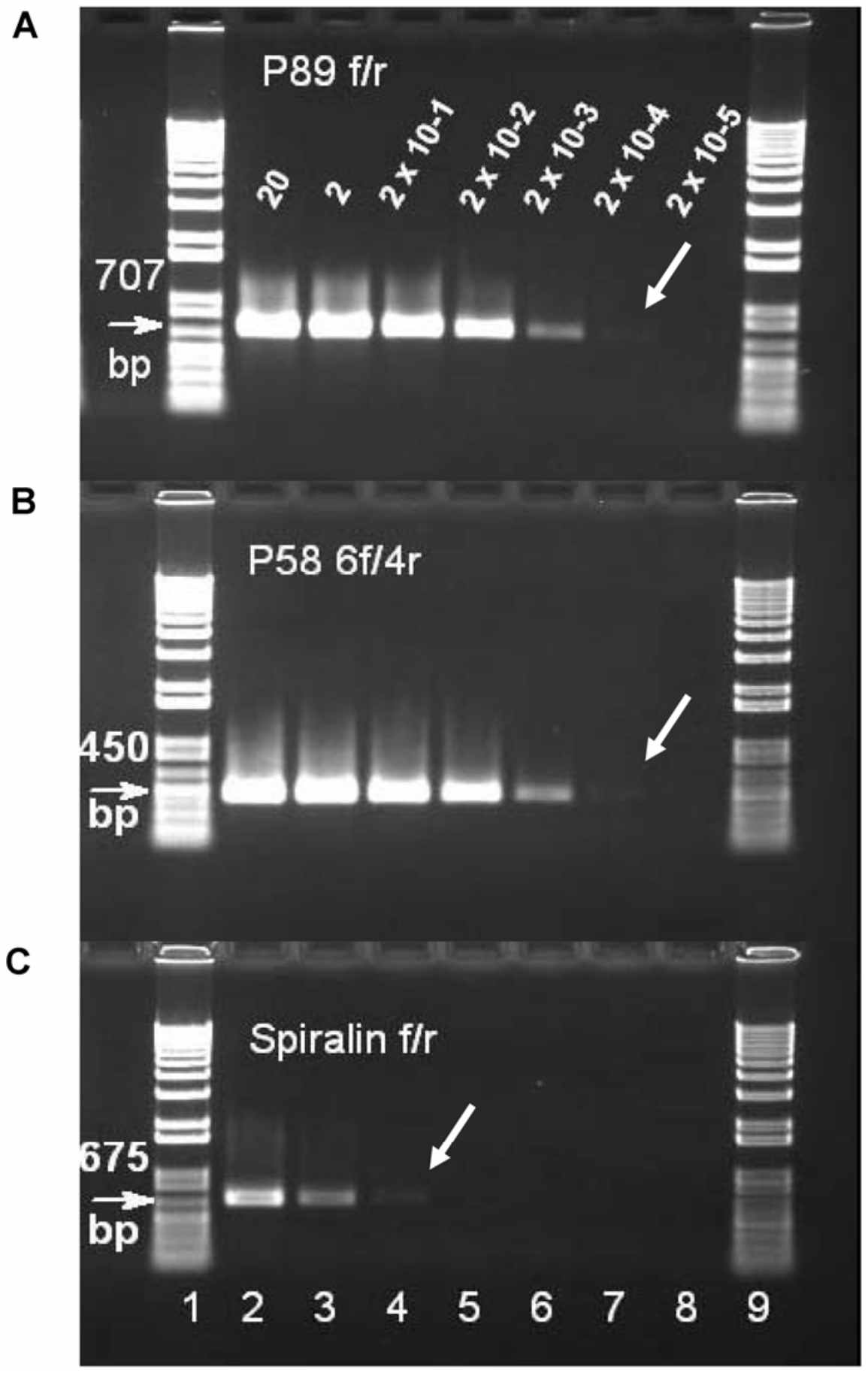

Fig. 3. Sensitivity of different primers for Spiroplasma citri detection by polymerase chain reaction. A, P89-f/r primers yields amplicon of size $707 \mathrm{bp}$; B, P58-6f/4r primers produce 450-bp amplicon; C, Spiralin-f/r (Spln) produce 675-bp amplicon. Initial quantity of $S$. citri DNA in lane 2 is $20 \mathrm{ng}$; dilution in lanes 3 to 8 is $10^{-1}, 10^{-2}, 10^{-3}, 10^{-4}, 10^{-5}$, and $10^{-6}$, respectively. Lanes 1 and 9 , DNA 1-kb-plus ladder; lane 8, deionized water control (DI). Arrow indicates last visible band.

base/primer pairs tested. Melt curves showed a single peak from DNA analyzed from infected samples whereas extracts from healthy tissue and no-template controls were always negative (flat line), indicating that no primer-dimer or nonspecific reactions occurred (Fig. 6A). Amplicons from real-time PCR were electrophoresed to show that the amplicons were of the expected size (86 and 119 bp; Fig. 6B and C).

Using P58-3f/4r, amplicons of expected size were produced from $S$. citri cultures and DNA extracts from columella of trees T4 and T9 from field 1 were detected (Figs. 7 and 8B). Use of primer pair P58$1 \mathrm{f} / 2 \mathrm{r}$ resulted in a cycle threshold $\left(\mathrm{C}_{\mathrm{t}}\right)$ value of 14 with $\mathrm{T} 9$ but produced no fluorescence with $T 4\left(C_{t}=0\right.$; Fig. 8A), a result similar to that observed with conventional PCR. In real-time PCR, T9 reacted like a group 1 isolate, whereas strain $\mathrm{T} 4$ reacted as a group 2 isolate. Hence, in conventional and real-time PCR, primers P586f/4r and P58-3f/4r were equivalent and primer pairs $\mathrm{P} 58-1 \mathrm{f} / 5 \mathrm{r}$ and $\mathrm{P} 58-1 \mathrm{f} / 2 \mathrm{r}$ were equivalent.

In these tests, the real-time PCR assay was able to detect less than $10^{-6} \mathrm{ng}$ (from picogram to fg levels) of $S$. citri DNA (Fig. $9)$. The standard curve had an average regression coefficient $\left(R^{2}\right)$ of 0.982 with a slope of -3.39 and its amplification effi-

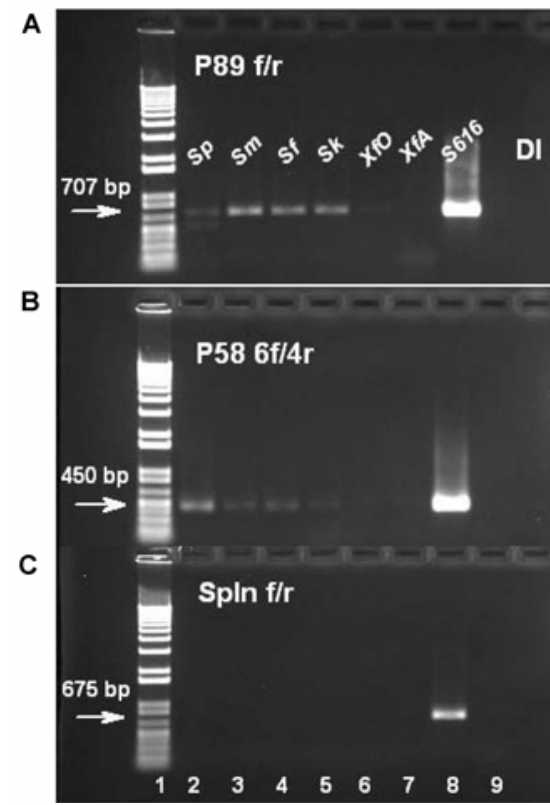

Fig. 4. Comparison of the specificity of the different primer pairs for the polymerase chain reaction detection of Spiroplasma citri. A, P891f/2r primer; B, P58-6f/4r primer; C, Spiralin-f/r primer. Sample DNA (10 ng) loaded per lane in lanes 2 to 8: $S p=$ Spiroplasma phoeniceum; $S m$ $=S$. melliferum; $S f=S$. floricola $; S k=S$. kunkelii; $X f O=$ Xylella fastidiosa, Ann-1 (ATCC 700598) oleander leaf scorch strain; and $X f A=X$. fastidiosa Dixon (ATCC 700965) almond leaf scorch strain. S616 = S. citri. Lane 1, DNA 1-kb-plus ladder; lane 9, deionized water control (DI). Arrows at left indicate amplicon sizes. 
ciency was over $97 \%$, indicating a good association between the amount of template and the $\mathrm{C}_{\mathrm{t}}$ values. Thus, an accurate estimation of $S$. citri DNA in the infected plant tissues was achieved.

The overall coefficient of variation obtained from replicate samples $(n=9)$ was 1.9 and indicated excellent reproducibility of the assay.

Validation of PCR to detect $S$. citri in field samples. Conventional PCR results with the new primers on DNA extracts from field trees showed a close association with culturing for $S$. citri from the same tissue sampled (Table 2). S. citri was cultured from 197 of the 761 trees tested in both field plots. From culture-positive trees, positive PCR results were obtained from $84.8 \%$ (162 trees) and $94.2 \%$ (180 trees) with primers $\mathrm{P} 89-\mathrm{f} / \mathrm{r}$ and P58-6f/4r, respectively. However, with culturenegative trees, bright PCR amplicons were present in 10 and 33 trees, respectively, with P89-f/r and P58-6f/4r, suggesting that cultivation was not $100 \%$ efficient. In contrast, PCR negatives were obtained from culture-positive samples in only $14.6 \%$ (29 trees) and 5\% (11 trees) with P89-f/r and P58-6f/4r primers, respectively. Hence, if using culturing as the standard, $\mathrm{P} 89-\mathrm{f} / \mathrm{r}$ and P58-6f/4r were 85 and $94 \%$ efficient. However, considering PCR positives determined by $\mathrm{P} 58-6 \mathrm{f} / 4 \mathrm{r}$ as the standard, PCR with P89-f/r is $90 \%$ efficient and culturing is $86 \%$ efficient. The PCR positives obtained from culture-negative samples far outnumbered the PCR negatives obtained from culture-positive trees. Considering all of the data, including those confirming healthy trees (negative for both culture and PCR), there was an overall agreement of $90 \%$ (685 of 761 trees) and $93.7 \%$ (713 of 761 trees) for PCR with the P89-f/r and P58-6f/4r primers, respectively.

Real-time PCR performed even better than either set of primer in conventional PCR. This protocol resulted in positive $C_{t}$ values for all culture positives and identified 40 additional positive samples from culture-negative trees (Table 2). Thus, both conventional and real-time PCR protocols with the newly developed primers were validated for $S$. citri detection in comparison with culturing. Comparing the primer sets tested, P89-f/r (conventional PCR) was less than $90 \%$ as effective as P58-6f/4r (conventional PCR) and P58-3f/4r (realtime PCR) for field sample detection of $S$. citri (Table 2).

Citrus stubborn disease incidence was estimated to be 58.3 and $3.7 \%$ in field 1 and field 2, respectively (Table 2).

Incidence of pattern 1 and pattern 2 strains in field plots. Differential field sample reactions in PCR were observed with the different P58 primer pairs with the field samples. In all, 235 trees were positive with $\mathrm{P} 58-6 \mathrm{f} / 4 \mathrm{r}$ versus 50 trees positive with $\mathrm{P} 58-1 \mathrm{f} / 5 \mathrm{r}$ in conventional PCR (Table 2). Thus, the P58-1f/5r prim- ers did not detect $S$. citri in 185 trees $(21.2 \%)$ that were positive with P58-6f/4r. On a per-plot basis, field 1 had $78.2 \%$ (175 of 222 trees) positive with both P58-6f/4r and P58-1f $/ 5 \mathrm{r}$. Similarly, field 2 had $76.9 \%$ (10 of 13 trees) positive with both P58 primer pairs in conventional PCR. These differential test results support a hypothesis that two groups of $S$. citri occur in the groves, as represented by group 1 and group 2 PCR patterns. These results provide field validation of our earlier finding of differential PCR reactions among the historical CCPP isolates S600, S616, and C189 maintained in the greenhouse.

\section{DISCUSSION}

Lee et al. (13) used nested PCR and primers based on $S$. citri $16 \mathrm{~S}$ rDNA sequence for the detection of $S$. citri in carrots suffering from stunting and purple to yellow-purple leaves in Washington State.
They further confirmed the presence of $S$. citri using spiroplasma virus-based primers. Barros et al. (1) reported developing PCR detection for corn stunt spiroplasma from unique regions of the nucleotide sequence for the $S$. kunkelli spiralin gene. Wei et al. (20) reported use of unique adhesin-like gene sequences in developing primers for real-time detection of $S$. kunkelli. For citrus stubborn disease, however, culturing has remained the primary method for detection of this pathogen in field samples.

Grafting experiments demonstrated that $S$. citri distribution in planta is erratic and the pathogen titer is generally low (12). For this reason, the authors recommended that inoculum collection for transmission tests and sampling to detect $S$. citri be limited to the hot summer months when $S$. citri titer is generally highest. In the past, researchers $(11,18)$ used primers derived

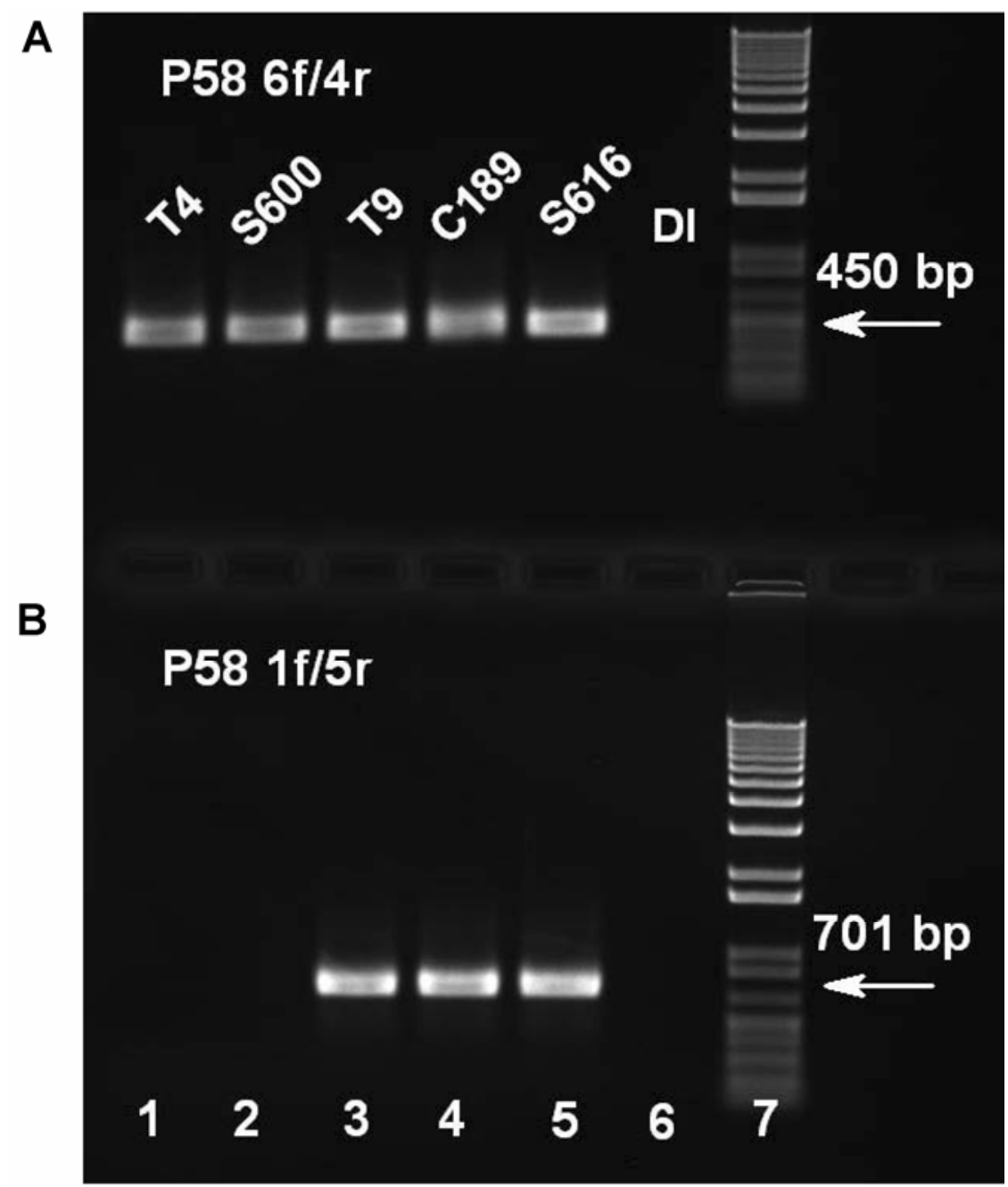

Fig. 5. Polymerase chain reaction detection of two different strains of Spiroplasma citri. A, P58-6f/4r primer; B, P58-1f/5r. T4 and T9 are strains of $S$. citri collected in field plots in Kern County, CA in November 2006; C189 is a strain propagated in a Madam Vinous sweet orange seedling from the culture collection of E. C. Calavan, University of California, Riverside (18); S600 was isolated from a citrus stubborn infected tree the Coachella Valley, CA in 1964; and S616 is an isolate of S. citri from a replacement tree (original in planta propagation was lost) from the Coachella Valley, CA obtained in the late 1960s (C. N. Roistacher, personal communication). C189, S600, and S616 have been maintained in planta continuously since its original collection. Lane 1, DNA 1-kb-plus ladder; lane 6, deionized water control (DI). 
from the gene for spiralin, which is present as a single copy in the chromosome of all $S$. citri strains examined (11), to detect $S$. citri. The data presented in the present report demonstrate that use of the spiralin primers in PCR provides suboptimal sensitivity, limiting its use for epidemiology studies in California to only the hot summer months. Therefore, we explored other gene sequences of $S$. citri for primers that would have greater sensitivity and would permit a rapid, season-independent method to identify $S$. citri-infected trees.

The $S$. citri putative adhesion-related protein, P89 (Sarp1), is present on a plasmid as well as the pathogen genome $(2,10,21)$ in all $S$. citri strains studied. P58, a putative adhesin multigene of $S$ citri, likely is present in multiple copies in the $S$. citri genome as a result of multiple viral inserts (8). For these reasons, primers were developed against GenBank sequences from both of these genes and selected primer pairs for $S$. citri specificity by BLAST analysis.

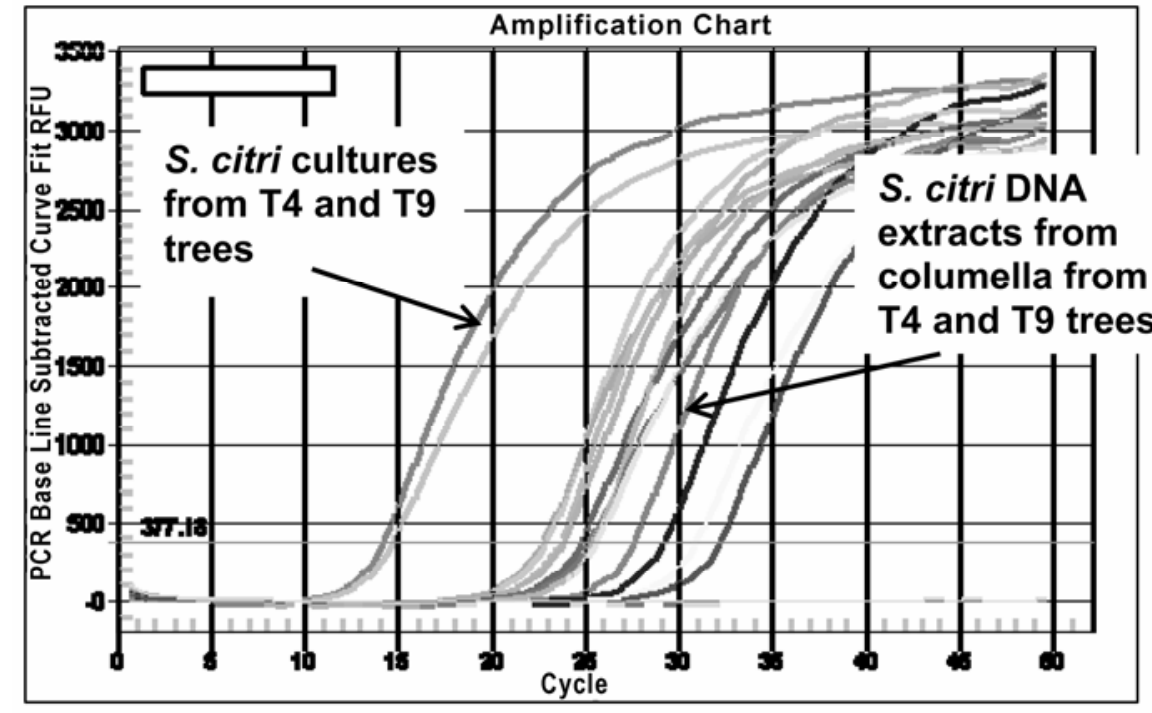

Fig. 7. Detection of Spiroplasma citri in field samples by real-time polymerase chain reaction using P58-3r/4f. A, T4 and T9 from cultures (average cycle threshold $\left[\mathrm{C}_{\mathrm{t}}\right]=14.5 \pm 0.4$ [standard deviation]) and DNA extracts from fruit columella (average $C_{t}=26.2 \pm 3.1$; range 22.7 to 32 ). $C_{t}$ values from 10 to 32 are positive for $S$. citri infection. $\mathrm{HC}=$ healthy control and $\mathrm{NTC}=$ no template control.

A
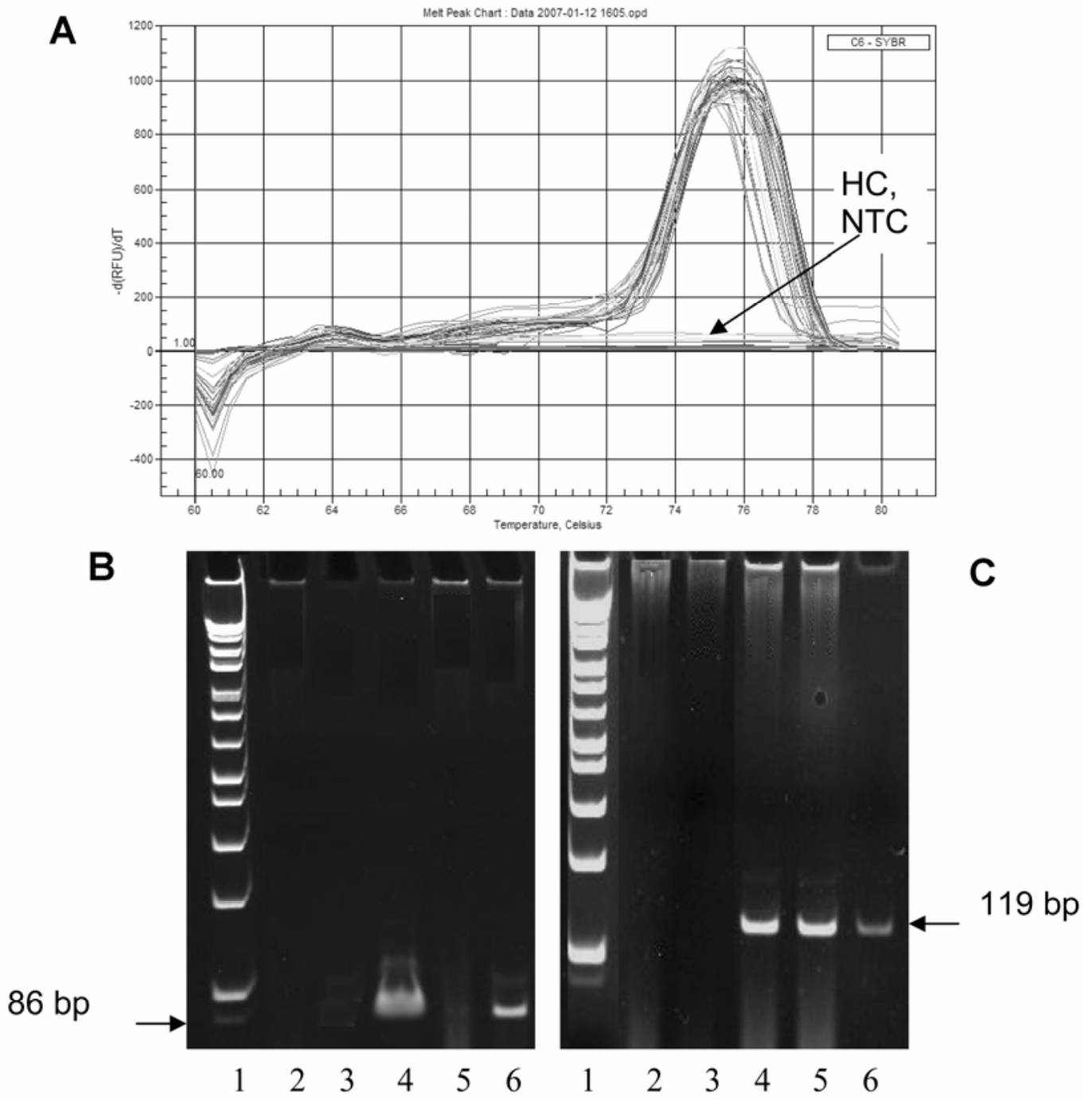

Fig. 6. Real-time polymerase chain reaction (PCR) product analyses. A, Melting peaks obtained using primers P58-3f/4r showing a single peak in the infected samples and the absence of peaks in the healthy and nontemplate controls. B, and C, Electrophoretic analysis in 5\% polyacrylamide gel stained with ethidium bromide of real-time PCR products obtained using primers P58-1f/2r and P58-3f/4r, respectively. Lane 1, 1-kb-plus ladder; lane 2, healthy control; lane 3, nontemplate control; lane 4, T9 S. citri culture; lane 5, DNA from T4 columella; and lane 6, DNA from T9 columella. 
Both the P89- and the P58-based primers were at least 1,000 times more sensitive than the spiralin primers. The close association of PCR with these primers with culture results validates the protocol for $S$. citri detection from field samples. In fact, the data suggest that PCR was better than culturing in identifying citrus stubborninfected trees. In addition, the real-time PCR assay proved to be sensitive, fast, and as reliable as conventional PCR. Through the selection of the primers, SYBR Green I successfully differentiated between group 1 and group 2 strains. In cases where the incidence of citrus stubborn disease is low or when the PCR amplicons are weak or $\mathrm{C}_{t}$ values are high (i.e., >35), the sample should be recollected and tested again. Because $S$. citri is not a phytoplasma and can be cultured, all dubious samples along with a few strong PCR positives should be confirmed by culturing.

The differentiation of $S$. citri groups using the protocols of the two P58-based primer pairs was unexpected. Two distinct groups were readily detected in samples when DNA purified from infected plants was used as the template in conventional PCR or real-time PCR. Further, S. citri was cultured from all these samples. The data presented indicated that group 1 isolates represent a strain having general reaction to P58-6f/4r; whereas group 2 isolates represent a different population that lacks homology in the P58 region characterized in the S. citri strain BR3-G (DQ 344811). Additional isolates tested in the Oklahoma lab using P58-6f/4r and P58-1/5r primers in PCR were separated into two reaction categories: (i) strong amplicons with P586f/4r and (ii) weak amplicons with P58$1 \mathrm{f} / 5 \mathrm{r}$ (data not shown). Nevertheless, the two different PCR reaction groups confirmed the presence of genetic diversity in $S$. citri populations evaluated in Parlier and Oklahoma.

Detection of both $S$. citri groups in the field samples show that the two populations coexist in nature. A higher proportion of samples were group 1 than group 2 . Similar diversity was observed among S600, S616, and C189 and suggested that these groups or populations have been present for more than 50 years in California and represent a stable level of genetic diversity previously unrecognized.

Early citrus stubborn researchers in California observed variations in symptom severity among citrus stubborn-infected trees. Calavan (6) suggested that this may be due in part to various strains of the pathogen. Numerous researchers studying the molecular biology of $S$. citri have reported variations of the pathogen with respect to plasmids, viral bacteriophage and mutants (5). Rangel et al. (17) mentioned some apparent genetic variability of $S$. citri populations collected from different portions of California based on preliminary amplified fragment length polymor-

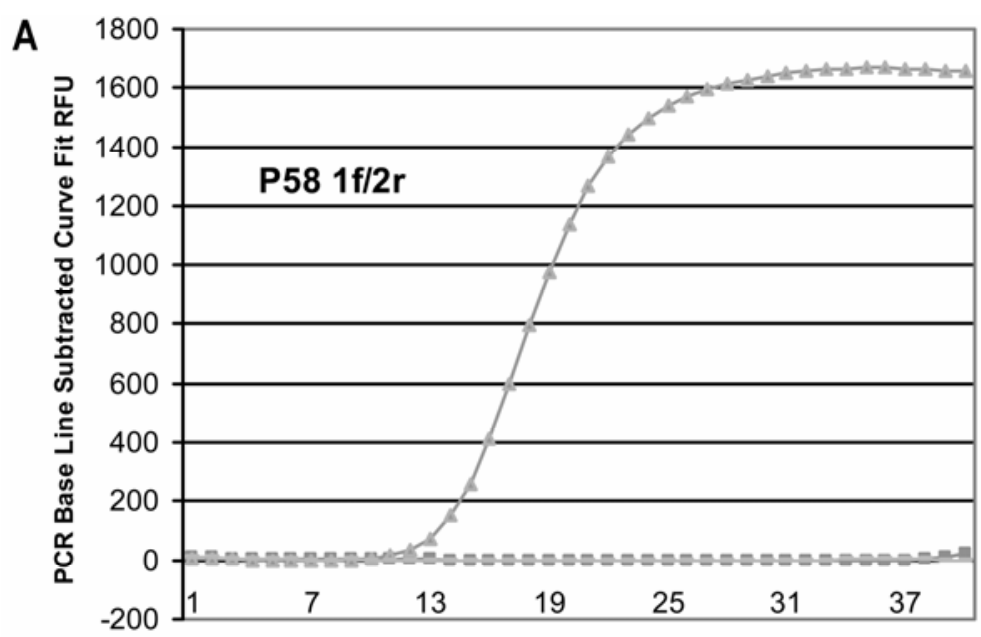

\section{Cycle threshold}

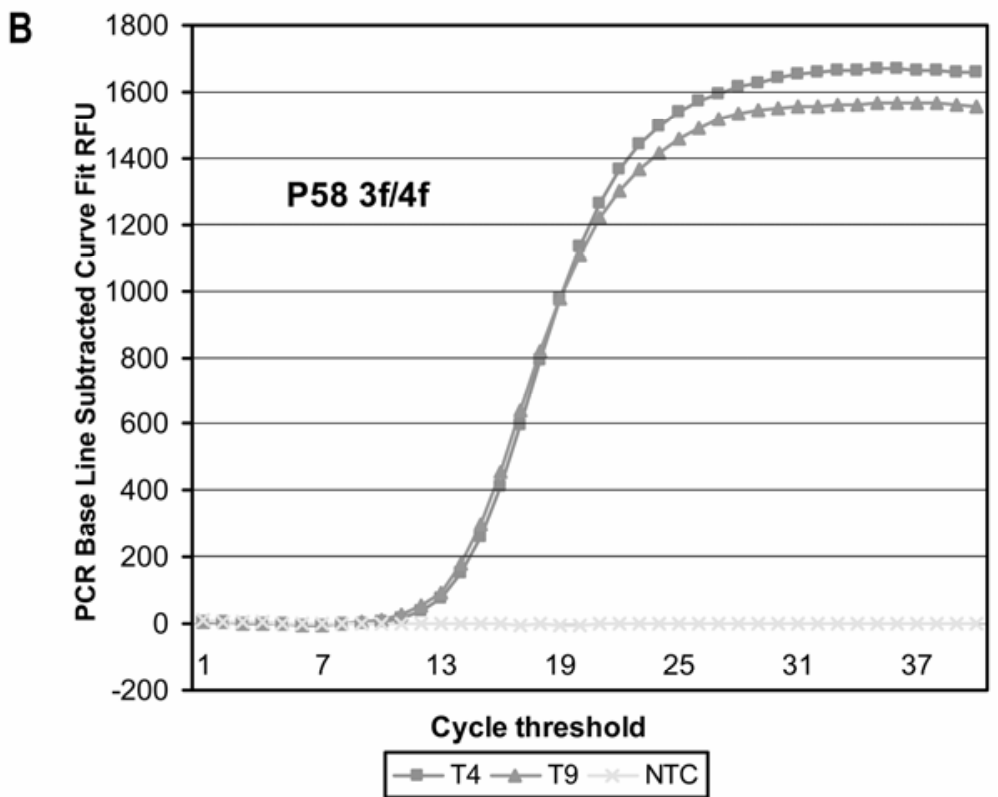

Fig. 8. Real-time polymerase chain reaction (PCR) results from cultures of $\mathrm{T} 4$ and $\mathrm{T} 9$ strains of Spiroplasma citri showing differential specificity between the primer pairs. A, Primer P58-1f/2r and B, primer P58-3f/4r. NTC $=$ no template control.

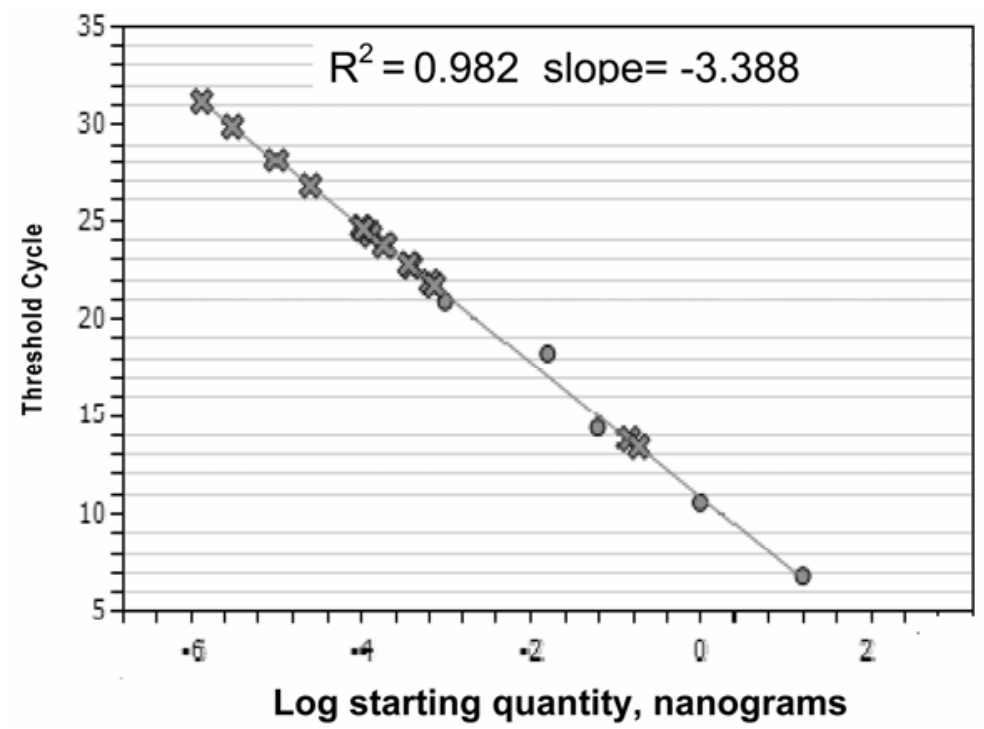

Fig. 9. Standard curve generated by serial fourfold dilution of plasmid DNA of Spiroplasma citri, showing relationship between starting DNA template spiked into healthy extracts and cycle threshold. 
Table 2. Polymerase chain reaction (PCR) results and comparison with culturing of Spiroplasma citri for citrus stubborn disease detection in trees from two Navel orange groves located in Kern County, $\mathrm{CA}^{\mathrm{a}}$

\begin{tabular}{|c|c|c|c|c|c|c|c|}
\hline \multirow[b]{3}{*}{ PCR type } & \multirow[b]{3}{*}{ Primer } & \multicolumn{6}{|c|}{ Number of trees } \\
\hline & & \multicolumn{3}{|c|}{ Field $1\left(384\right.$ trees in plot and LD8+ $\left.=191^{b}\right)$} & \multicolumn{3}{|c|}{ Field $2\left(377\right.$ trees in plot and LD8 $\left.+=6^{b}\right)$} \\
\hline & & Positive PCR & LD8 missed & PCR missed & Positive PCR & LD8 missed & PCR missed \\
\hline Conventional & P89-f/r & 199 & 37 & 29 & 11 & 3 & 1 \\
\hline Conventional & P58-6f/4r & 222 & 42 & 11 & 13 & 8 & 1 \\
\hline Real time & $\mathrm{P} 58-3 \mathrm{f} / 4 \mathrm{r}$ & 224 & 40 & 0 & 14 & 10 & 2 \\
\hline Conventional & P58-1f/5r & $47^{c}$ & $\ldots$ & $\ldots$ & $3^{\mathrm{d}}$ & $\ldots$ & $\ldots$ \\
\hline
\end{tabular}

a Samples collected in August 2006

${ }^{\mathrm{b}}$ Number of trees with positive cultures of $S$. citri in LD8 liquid medium.

${ }^{c}$ Field 1. PCR group 2 pattern (amplicon with P58-6f/4r primers pair but no amplicon with P58-1f/5r primer pair) was present in $47 / 222=21.2 \%$ of the population. Therefore, group 1 pattern (amplicons with P58-6f/4r primers pair and with P58-1f/5r primer pair) was present in 175/222 = 78.2\% of the population.

${ }^{\mathrm{d}}$ Field 2. PCR group 2 pattern $=3 / 13=23.1 \%$ of the population. Therefore, group 1 pattern was present in $10 / 13=76.9 \%$ of the population .

phism marker data. However, to our knowledge, this study is the first to document stable genetic diversity from field populations of citrus stubborn-infected trees.

In summary, this report describes newly developed primers which greatly increased the sensitivity of PCR for the detection of $S$. citri and also distinguished between two genetic strains of $S$. citri. Culturing for $S$. citri detection is expensive, laborious, and time consuming. In contrast, the PCR protocols described here are rapid and sensitive. In addition, with greater acceptance of PCR platforms in detection technologies, reagents recently have become more economical. Hence, PCR-based detection of $S$. citri from large numbers of field trees is now feasible and can be employed in future epidemiology studies of citrus stubborn disease.

\section{ACKNOWLEDGMENTS}

M. Saponari is from the Istituto di Virologia Vegetale del CNR, Sezione di Bari, Via Amendola 165/A, 70126 Bari, Italy and was a Visiting Scientist in the Crop Diseases, Pest, and Genetic Research Unit (CDPG), USDA-ARS, Parlier, CA. We thank R. L. DeBorde and A. Gonzalez, CDPG, USDA-ARS, Parlier, CA for technical assistance in the laboratory and field; E. L. Civerolo and J. C. Chen, USDA-ARS, Parlier, CA for valuable insights on this project; U. Melcher, Oklahoma State University, Department of Entomology \& Plant Pathology, Stillwater for providing additional information on the S. citri P58 gene; and R. Krueger and B. Rangel, USDA-ARS, National Clonal Germplasm Repository for Citrus and Dates, Riverside, CA for providing samples. A portion of this research was supported by USDAARS Project No. 5302-22000-007-15 and the Oklahoma Agricultural Experiment Station, Hatch Project 2052.

\section{LITERATURE CITED}

1. Barros, T. S. L., Davis, R. E., Resende, R. O., and Dally, E. L. 2001. Design of a polymerase chain reaction for specific detection of corn stunt spiroplasma. Plant Dis. 85:475-480.

2. Berho, N., Duret, S., and Renaudin, J. 2006. Absence of plasmids encoding adhesionrelated proteins in non-insect-transmissible strains of Spiroplasma citri. Microbiology 152:873-886

3. Bové, J. M., Foissac, X., and Saillard, C. 1993. Spiralins. Subcell. Biochem. 20:203-223.

4. Bové, J. M., and Garnier, M. 2000. Stubborn. Pages 48-50 in: Compendium of Citrus Diseases. L. W. Timmer, S. M. Garnsey, and J. H. Graham, eds. American Phytopathological Society Press, St. Paul, MN.

5. Bové, J. M., Renaudin, J., Foissac, X., Gaurivaud, P., Carle, P., Laigret, F., Saillard, C., and Garnier, M. 2002. Spiroplasma citri: from functional genomics to genomics. Pages 278-287 in: Proc. 15th Conf. Int. Organ. Citrus Virol. N. Duran-Villa, R. G. Milne, and J. V. da Graça, eds. IOCV, Riverside, CA.

6. Calavan, E. C. 1969. Investigations of stubborn disease in California: indexing, effects on growth and production, and evidence for virus strains. Pages 1403-1412 in: Proc. 1st Int. Citrus Symp. Vol. III.

7. Calavan, E. C. 1979. Symptoms of stubborn disease and the culture of Spiroplasma citri. Pages 67-72 in: Proc. R.O.C.-U. S. Coop. Sci. Semin. Mycoplasma Dis. Plants. NSC Symp. Ser. No. 1. National Science Council, Republic of China.

8. Comer, J., Fletcher, J., Davis, R. E., and Melcher, U. 2007. Evolution of the spiroplasma P58 multigene family. Biochem. Genet. 45:25-32.

9. Doyle, J. J. 1991. DNA protocols for plants. Pages 283-293 in: Molecular Techniques in Taxonomy. G. Hewitt, A. W. B. Johnson, and J. P. W. Young, eds. NATO ASI Ser. H, Cell Biol. Vol. 57.

10. Fletcher, J., Shaw, M. E., Baker, G. R., Dugan, K. J., Ye, F., Sha, Y., Zuck, P. D., and Myers, G. D. 1996. Molecular characterization of Spiroplasma citri BR3 lines that differ in transmissibility by leafhopper Circulifer tenellus. Can. J. Microbiol. 42:124-131.

11. Foissac, X., Saillard, C., Gandar, J., Zreik, L., and Bové, J. M. 1996. Spiralin polymorphism in strains of Spiroplasma citri is not due to differences in posttranslational palmitoylation. J. Bacteriol. 178:2934-2940.
12. Gumpf, D. J., and Calavan, E. C. 1981. Stubborn disease of citrus. Pages 97-134 in: Mycoplasma Diseases of Trees and Shrubs. K. Maramorosch and S. P. Raychaudhuri, eds. Academic Press, New York.

13. Lee, I.-M., Bottner, K. D., Munyaneza, J. E., Davis, R. E., Crosslin, J. M., du Toit, L. J., and Crosby, T. 2006. Carrot purple leaf: a new spiroplasmal disease associated with carrots in Washington State. Plant Dis. 90:989-993.

14. Lee, I.-M., and Davis, R. E. 1983. New media for rapid growth of Spiroplasma citri and corn stunt spiroplasma. Phytopathology 74:84-89.

15. Oldfield, G. N., Sullivan, D. A., and Calavan E. C. 1984. Inoculativity of leafhopper vectors of stubborn disease in California. Pages 125130 in: Proc. 9th Conf. Int. Organ. Citrus Virol. S. M. Garnsey, L. W. Timmer, and J. A. Dodds, eds. IOCV, Riverside, CA.

16. Oldfield, G. N., Yokomi, R. K., Golino, D. A., and Gumpf, D. J. 1991. Flight phenology of Circulifer tenellus and other leafhoppers in San Joaquin Valley citrus groves. Pages 441447 in: Proc. 11th Conf. Int. Organ. Citrus Virol. R. H. Brlansky, R. F. Lee, and L. W. Timmer, eds. IOCV Riverside, CA.

17. Rangel. B., Krueger, R., and Lee, R. F. 2005. Current research on Spiroplasma citri in California. Pages 439-442 in: Proc. 16th Conf. Int. Organ. Citrus Virol. M. E. Hilf, N. DuranVilla, and M. Rocha-Peña, eds. IOCV, Riverside, CA.

18. Saglio, P., Lhospital, M., Laflèche, D., Dupont, G., Bové, J. M., Tully, J. G., and Freundt, E. A. 1973. Spiroplasma citri gen. and sp. n.: a Mycoplasma-like organism associated with "stubborn" disease of citrus. Int. J. Syst. Bacteriol. 23:191-204.

19. Tully, J. G. 1983. Dark-field microscopy. In: Methods in Mycoplasmology. S. Razin and J. G. Tully, eds. Academic Press, New York.

20. Wei, W., Opgenorth, D. C., Davis, R. E., Summers, C. G., and Zhao, Y. 2006. Characterization of a novel adhesion-like gene and design of a real-time PCR for rapid, sensitive, and specific detection of Spiroplasma kunkelii. Plant Dis. 90:1233-1238.

21. Yu, J., Wayadande, A., and Fletcher, J. 2000. Spiroplasma citri surface protein P89 implicated in adhesion to cells of the vector Circulifer tenellus. Phytopathology 90:716-722. 